ZN WSH Zarządzanie 2019 (3), s. 21-33

Oryginalny artykuł naukowy

Original Article

Data wpływu/Received: 1.07.2019

Data recenzji/Accepted: 18.10.2019/15.10.2019

Data publikacji/Published: 30.09.2019

Źródła finansowania publikacji: środki własne

DOI: $10.5604 / 01.3001 .0013 .7238$

Authors' Contribution:

(A) Study Design (projekt badania)

(B) Data Collection (zbieranie danych)

(C) Statistical Analysis (analiza statystyczna)

(D) Data Interpretation (interpretacja danych)

(E) Manuscript Preparation (redagowanie opracowania)

(F) Literature Search (badania literaturowe)

Dr hab. Yevhenii Alimpiiev ${ }^{A D F}$

Uniwersytet Łódzki

ORCID 0000-0002-5998-6535

Ph.D. Stanislav Dubikovsky ${ }^{A C D E F}$

Institute of Social and Economic Development, Kyiv

Prof. D.Sc. Volodymyr Tokar ${ }^{D E}$

Kyiv National Economic University named after Vadym Hetman

ORCID 0000-0002-1879-5855

\title{
SUSTAINABLE DEVELOPMENT DETERMINANTS \\ OF AN INFORMATION SOCIETY: CASE STUDY \\ OF NATIONAL ECONOMIES
}

DETERMINANTY ZRÓWNOWAŻONEGO ROZWOJU SPOŁECZEŃSTWA INFORMACYJNEGO STUDIUM PRZYPADKU GOSPODARKI NARODOWEJ 
Abstract: We analyze social-economic models of countries with developed information economies using group method of data handling. We identified the determinants of optimal model for social and economic development of countries with developed information societies. The experience of countries with developed information economy show that their success and high level of competitiveness rely on adequate determination of prospective development directions and effective implementation of innovations in production. Countries-leaders by IT-industry, show higher indicators of competitiveness and living standards. The high employment rates guarantee the dynamic economy and civil society. Implementing strategies for social and economic development of countries with developed information economy maximally ensure the protection of national economic interests. Therefore, the models for sustainable social and economic development objectively form the basis of economic security.

Keywords: sustainable development, information society, group method of data handling, strategy for social and economic development, economic security

Streszczenie: W artykule analizowane są społeczno-ekonomiczne modele krajów o rozwiniętych gospodarkach informacyjnych przy użyciu grupowej metody przetwarzania danych. Określono determinanty optymalnego modelu rozwoju społeczno-gospodarczego krajów o rozwiniętych społeczeństwach informacyjnych. Doświadczenia krajów o rozwiniętej gospodarce informacyjnej wskazują, że ich sukces oraz wysoki poziom konkurencyjności opierają się na odpowiednim określeniu perspektywicznych kierunków rozwoju i skutecznym wdrażaniu innowacji. Kraje wiodące w branży IT wykazują wyższe wskaźniki konkurencyjności i standardów życia. Wysokie wskaźniki zatrudnienia gwarantują dynamiczny rozwój gospodarki i społeczeństwa. Wdrażanie strategii rozwoju społeczno-gospodarczego krajów o rozwiniętej gospodarce informacyjnej maksymalnie zapewnia ochronę narodowych interesów gospodarczych. Dlatego modele zrównoważonego rozwoju społecznego i gospodarczego obiektywnie tworzą podstawę bezpieczeństwa ekonomicznego.

Słowa kluczowe: zrównoważony rozwój, społeczeństwo informacyjne, grupowa metoda przetwarzania danych, strategia rozwoju społecznego i gospodarczego, bezpieczeństwo ekonomiczne

\section{Introduction}

The dynamic technological development is the key reason for transition from an industrial society to an information one, in other words, a post-industrial knowledge society. Information and knowledge are strategic resources, while ICT market becomes one of the most powerful information economic sector. An information economy, a new type, fosters the establishment and development of the information society (Industry 4.0) as the new development stage of the human civilization ${ }^{1}$.

The information economy essentially differs from a "commodity economy" shaping new social relationships emerging due to new information technologies

1 K. Schwab, The Fourth Industrial Revolution, Crown Business, New York 2017. 
(networks) and transforming production relations of the industrial society. This new type of economy has no national borders as networks, information and communication technologies are global phenomena.

The modern national economy, economic independence and potential for development are the key parameters of the national security.

\section{Theoretical background}

A rich variety of economic, social and cultural models for developing information society is the reflection of our diversity and multicultural nature of the modern world. Economic growth and development are interconnected notions, but the sustainable development is the supreme one forming the basis for the long-run economic growth.

Joseph Schumpeter was the first one to differentiate economic development and growth, determine the essence and classification of innovations ${ }^{2}$. According to this economist and sociologist, economic growth is the increase in production and consumption of the same products and services (quantitative changes in time). The economic development is the novelty in production, management, goods, services, and economy as a whole, in other words, innovations. Therefore, the economic development is the creation and development of innovative economic sector, economic growth, structural changes in economy, enhancement of labor productivity and quality-of-life in the community.

In general, there are American (US, Canada, Australia), Western European (Sweden, Finland, Norway, Germany, France, etc.) and Oriental (Japan, China, "Asian Tigers") economic models by geopolitical criterion. Each type of economic models has its own features determining the effective functioning.

The American model of social and economic development holds a leading position in the world. This model minimizes the role of the government and maximizes the role of private agents. All elements aim at fostering entrepreneurship, liberalization of the market for information and communication technologies. Means of production mostly belong to private owners, and the market coordinates the interaction between economic agents. Programs stimulating social equality do not exist, but there are some benefits and social help for the poor aiming at providing them with appropriate minimum living standards. The key principle is personal success and enriching the most active inhabitants.

The modern Western European economy and culture are the result of long centuries of evolution of inter-connected and inter-dependent nations. This interplay provided the basis for European integration and determines the peculiarities of the

\footnotetext{
2 J. Shumpeter, Theory of Economic Development. Capitalism, Socialism and Democracy, EKSMO,
} Moscow 2007. 
Western European socially oriented market model, which is somewhat different from the American neoliberal model. Firstly, the state sector and the state itself play the significant role in European economy. Secondly, while the American model praises the prevalence of individual over solidarity, the European model promotes the balance between them. In theory, social and market model is more stable and attracts by its social orientation providing the guaranteed standards for citizens.

Nowadays, Germany is one the most developed countries determining the growth tempos of the European Union. The key features of German model are: the high share of state property in the economy and significant influence of the state on economic development; forecasting of the main macroeconomic indicators; insignificant income differentiation between managers and other employees; social orientation.

The Chinese model, as well as the Japanese one, relies on traditional oriental values, but with more emphasis on own natural resources, state economic planning, state ownership on means of production, the prevalence of labor-intensive technologies and achieving competitive advantages, clear social orientation. The bulk of state R\&D investments and attracting foreign investments guarantee the positive effects. China transformed from the underdeveloped country into the world leader in telecommunication ${ }^{3}$.

All the above-mentioned models develop dynamically with the tendency to convergence, especially, the EU member-states deregulating labor markets and weakening the state influence on employees' living standards, in other words, lowering some social standards. At the same time, American and Japanese models shift towards increasing the social standards guaranteed by the government.

The notion "information society" includes the unified information industry developing against the backdrop of the constantly growing role of knowledge and information in economy.

Considering all the above mentioned, we assume that the key features of generalized secure sustainable development model are: defending national spiritual and moral values; civil society development; defined and clear social and economic development strategy; high level of national consciousness and readiness of citizens to sacrifice in order of the national prosperity; social orientation of the economy; minimization of income differentiation; maximization of $\mathrm{R} \& \mathrm{D}$ expenses, development of information and communication technologies and infrastructure; harmonized combination of state and market mechanisms; effective national and business management; ensuring the inclusive employment; environmental protection; a carefully considered national information geopolitics.

Countries-leaders with developed information economy are able to counteract and minimize threats and risks to individuals, society and the state providing oth-

3 S. Dubikovsky, The End of Epoch: the Fatal Choice of Humanity, Fiery Lel, Kyiv 2019. 
er entities with necessary tools for building own successful information-intensive models of national sustainable development.

\section{The aim and methodology of research}

There is an abundant literature on concepts and models of economic development and security with the system of dominant indicators featuring macroeconomic, foreign trade, investment, social and other dimensions of economy. The roaster of such indicators describes social and economic characteristics, sometimes with time correlation. The comparison of actual values of indicators with threshold ones helps to determine weaknesses and elaborate the means for minimizing the impact of negative factors on national economy. Such approach is useful for depicting national social and economic development in certain periods. Researchers usually try to determine the level of economic development and/or security applying the target functions (Figure 1):

$$
f(t)=\sum_{i=1}^{n} k_{i} x_{i}=k_{1} x_{1}+k_{2} x_{2}+\ldots+k_{n} x_{n}
$$

where $\mathrm{x}_{(1 \ldots \mathrm{n})}$ - the key indicators of economic functioning (for example, $\mathrm{x}_{1}-\mathrm{GDP}, \mathrm{x}_{2}$ - state debt, $\mathrm{x}_{3}$ - foreign trade turnover);

$\mathrm{k}_{(1 \ldots \mathrm{n})}$ - weighting factors of indicators.

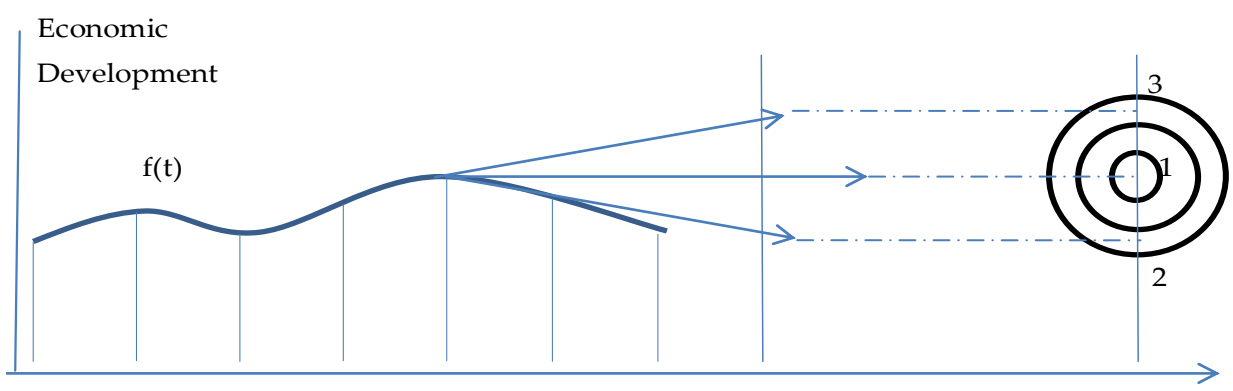

Figure 1. Dynamics of the target function development for national economy Rysunek 1. Dynamika rozwoju funkcji celowej dla gospodarki narodowej Source: own processing.

It is necessary to reach at least threshold values of indicators for economic development and security, because if this rule is violated, then destructive tendencies are observed. It is worth mentioning, that the highest level of economic security is achieved only if all the indicators are within permissible range of values. 
Figure 1 shows that the direction of the target function $\mathrm{f}(\mathrm{t})$ to the center is the optimum one. Therefore, the deviation of factor $\mathrm{f}(\mathrm{t})$ to values depicted by states of nature 2 and 3 indicates a certain zone of risks and threats for the national economic security. Thanks to such approach of determining the optimum target function of the national economic security with further comparison of actual values with theoretical ones, it is possible to detect negative tendencies and work out in-time managerial decisions.

However, we consider such methodology to be not quite correct. Firstly, due to its reliance on uncertainty of threshold values of indicators of economic development and security, it provides only limited ability for statistical observance over changes in the national economy. Secondly, the equation of the target function includes $x 1$ (GDP) and other indicators that actually influencing GDP. Thirdly, the necessary condition for applying traditional statistical methods of modeling is the normal distribution (Gauss) of variables, but in reality, we analyze the dynamic national economic system influenced by even more dynamic global economic system.

Modern massive arrays of information determine that analysis, classification and preliminary information processing are conditions of effective developing and applying economic and mathematical models. Therefore, the analysis, modeling and forecasting macroeconomic processes requires the direct formulation of models based on statistical or experimental data, as they have advantages of detecting latent casual links and patterns of initial data and providing them in the form of realistic mathematical models.

The abovementioned problems can be solved applying the Group Method of Data Handling $(\mathrm{GMDH})^{4}$, which enables finding out information and knowledge on objects based on a sample. GMDH is the method of inductive modeling and one of the most effective methods for structural and parametric identification of complex objects, processes and systems based on statistical observance under conditions of lack of incomplete information. In practice, GMDH methodology is used to model economic, financial, ecological, medical, technological and military objects 5 .

GMDH consists of several basic algorithms. It includes parametric and cluster algorithms, complicated equivalents, and probability algorithms. This self-organization approach relies on permutation of models with their gradual complication and selecting the best solution based on the minimum of external criterion. As basic models, it uses polynomial, non-linear, probability functions and/or cluster recognition ${ }^{6}$.

\footnotetext{
${ }^{4}$ G.A. Ivakhnenko, Inductive Methods of Analysis and Forecasting of Complex Economic Systems. Cybercenter of the National Academy of Sciences of Ukraine, Natonal Institute for Strategic Research, Kyiv. Available online: http://www.GMDH.net (accessed on 25 January 2019).

5 M.H. Ahmadi, M.A. Ahmadi, M. Mehrpooya, M.A. Rosen, Using GMDH Neural Networks to Model the Power and Torque of a Stirling Engine, Sustainability, 2015, 7 (2), 2243-2255; L. Yang, H. Yang, H. Liu, GMDH-Based Semi-Supervised Feature Selection for Electricity Load Classification Forecasting. Sustainability, 2018, 10 (1), 217; K. Dumor, L. Yao, Estimating China's Trade with Its Partner Countries within the Belt and Road Initiative Using Neural Network Analysis, Sustainability, 2019, 11 (5), 1449.

6 A.G. Ivajhnenko, The Inductive Method of Complex System Self-organization, Naukova Dumka, Kyiv 1981.
} 
The authors of GMDH state, the general formulation of tasks of a structural and parametric identification or elaborating models based on experimental (statistical) data could be confined to searching for some criterion $C R$ in a set of different models ${ }^{\mathfrak{I}}$ :

$$
f^{*}=\underset{f \in \mathfrak{I}}{\operatorname{argmin}} C R(f)
$$

Let us assume, that we have a certain sample $\mathrm{W}=\left[\mathrm{X}_{\mathrm{y}}\right]$ with $\mathrm{n}$ points of observance forming a matrix $X=\left\{x_{i j}, i=1, \ldots, n ; j=1, \ldots, m\right\}$ an a vector $y=\left(y_{1} \ldots y_{m}\right)^{T}$ so, that $\mathrm{n} \geq \mathrm{m}$. Generally, the process of solving the tasks of structural and parametric identification consists of the following main stages:

1) Setting the sample of data and a priory information,

2) Selecting or setting the class of basic functions and conversion of data,

3) Generating different structures of models in a chosen class,

4) Estimating parameters of generated structures and forming the set $F$,

5) Minimizing the set criterion $C R(f)$ and selecting the optimal model $f$,

6) Verifying the adequacy of a found optimal model,

7) Making the decision to finalize the process.

Generally, the identification task is forming a certain set of models of different structure based on a sample:

$$
\hat{y}_{f}=f\left(X, \hat{\theta}_{f}\right)
$$

In addition, searching for an optimal model fulfilling the condition:

$$
f^{*}=\underset{f \in F}{\operatorname{argmin}} C R\left(y, f\left(X, \hat{\theta}_{f}\right)\right),
$$

Besides, estimating parameters ( 1 and 2 ) for each model $\mathrm{f} \in \mathrm{F}$ is solution of one of extreme tasks:

$$
\hat{\theta}_{f}=\arg \min _{\theta_{f} \in R^{s f}} Q R\left(y, X, \theta_{f}\right)
$$

where $s_{f}$ is the complexity of model $f$ and equals to the amount of unknown parameters in model $f(4)$;

$Q R$ - criterion of quality of solution of a task of parametric identification of each model generated in a task of structural identification ${ }^{7}$.

The majority of GMDH algorithms apply the basic polynomial function. This method enables the simultaneous selection of optimal structure of a model and dependence of output parameters on the most significant input parameters of a system.

The inductive modeling relies on statistical networks, which are educable and networks of mathematical functions finding complex non-linear links in a concise form. These networks divide a problem into a manageable parts or blocks, and then automatically apply developed regression methods for solving each of these simplified problems.

7 G.A. Ivakhnenko, Inductive Methods of Analysis..., p. 5. 


\section{Results}

As stated above, existing methods for calculating the target function of national economic security turned out to be not quite correct. Therefore, GMDH was used to research models for sustainable social and economic development as the best models of economic security for developed countries.

The first stage of inductive GMDH algorithm is setting a sample. Table 1 presents the selection of countries with information economy based on the "Ranking of countries by the Level of Development of the IT-industry" calculated relying on data provided by the World Economic Forum ${ }^{8}$.

Table 1. The Ranking of Countries by the Level of Development of the IT-industry according to the World Economic Forum in 2000-2016

Tabela 1. Ranking krajów według poziomu rozwoju branży IT według Światowego Forum Ekonomicznego w latach 2012-2016

\begin{tabular}{|l|c|c|c|c|c|}
\hline \multicolumn{1}{|c|}{ Country } & $\begin{array}{c}\text { Ranking } \\
\mathbf{2 0 1 6}\end{array}$ & $\begin{array}{c}\text { Ranking } \\
\mathbf{2 0 1 5}\end{array}$ & $\begin{array}{c}\text { Ranking } \\
\mathbf{2 0 1 4}\end{array}$ & $\begin{array}{c}\text { Ranking } \\
\mathbf{2 0 1 3}\end{array}$ & $\begin{array}{c}\text { Ranking } \\
\mathbf{2 0 1 2}\end{array}$ \\
\hline Singapore & 1 & 1 & 2 & 2 & 2 \\
\hline Finland & 2 & 2 & 1 & 1 & 3 \\
\hline Sweden & 3 & 3 & 3 & 3 & 1 \\
\hline Norway & 4 & 5 & 5 & 5 & 7 \\
\hline USA & 5 & 7 & 7 & 9 & 8 \\
\hline Netherlands & 6 & 4 & 4 & 4 & 6 \\
\hline Japan & 10 & 10 & 16 & 21 & 18 \\
\hline Canada & 14 & 11 & 17 & 12 & 9 \\
\hline Iceland & 16 & 19 & 17 & 17 & 15 \\
\hline New Zealand & 17 & 17 & 20 & 20 & 14 \\
\hline Ireland & 25 & 25 & 27 & 27 & 25 \\
\hline China & 59 & 62 & 62 & 58 & 51 \\
\hline India & 91 & 89 & 81 & 73 & 75 \\
\hline
\end{tabular}

Source: own processing based on? .

We chose and calculated dominant indicators (their absolute values in millions US dollars). These indicators indicate the openness of an economy, which is the sign of information economy.

\footnotetext{
8 The Global Information Technology Report, Available online: http://www3.weforum.org/docs/ GITR2016/WEF_GITR_Full_Report.pdf (accessed on 25 January 2019).

9 Ibidem.
} 
We divided the selected indicators into two groups - macroeconomic and inherent to information economy:

1. Macroeconomic Indicators: GDP, millions of US dollars; GDP per capita, millions of US dollars; Foreign trade turnover per capita, millions of US dollars; State debt, millions of US dollars; Foreign debt, millions of US dollars,

2. Indicators of Information economy: High-Tech commodity export, millions of US dollars; ICT commodity export, millions of US dollars; ICT commodity import, millions of US dollars; GERD, Gross Expenditure on R\&D, millions of US dollars; ICT service export, millions of US dollars; ICT service import, millions of US dollars.

Besides, as information and communication technologies play the significant role in countries with developed information economy and their proportion in GDP reaches more than 70 percent, then all indicators are significant.

The value of GDP is the main real quantitative parameter of estimation of the condition of social and economic development of a country. GDP affects indirectly on protection of national values. However, economic development and security depends on not only the value, but also the structure of GDP, namely dominant components influencing its forming. Besides, the economic security of countries with developed information economy has bi-directional functional dependence with GDP. The greater value of GDP enhances the national security, and vice versa, the higher level of national security enables the increase of GDP.

Therefore, we formulate the problem of solving the task of identification of functional dependence:

$$
Y=f(X) \text {, }
$$

where $Y=\left\{y_{1}, y_{2}, \ldots, y_{m}\right\}$ - the set of features of information economy, or the reaction of a system (the value of GDP, a target function); $X=\left\{\mathrm{x}_{1}, \mathrm{X}_{2}, \ldots, \mathrm{x}_{\mathrm{n}}\right\}$ - features of conditions, which form it, or variables influenced by the government (input factors).

As the result of modeling, we received and verifies adequate inductive models describing forming the GDP using features of the array X. These models are built using one consequence and verified applying another one. In our case, a random model was created using consequences in 2000-2015, but it was verified in multidimensional space of features of the array X (by points of observance) in 2016-2018. The data for this model were synthesized and grouped by certain similar features in 7 clusters. The coefficients of influence of variables of models, which have the greatest impacts, mean the biggest impact of these indicators on the GDP growth.

GMDH uses clusters, namely unsupervised learning, when classes of input data are not known in advance ${ }^{10}$. We use clusters to divide the set of objects into homogeneous groups - cluster. If, e.g., we imagine the sample data as point in the space with

${ }_{10}$ G.A. Ivakhnenko, Inductive Methods of Analysis..., p. 9. 
certain features, then the task of clusters is to determine the constellation of points. The aim of clusters is the search for existing structures. Creating clusters is the descriptive procedure, it does not lead to any statistical conclusions, but provides with the opportunity of profound analysis and structural research. Thus, the cluster is the group of objects with similar features.

We applied GMDH to synthesize, approbate, verify and divide into seven clusters based on similar features. Each cluster included a group of national economies in different periods and was reflected in a specific mathematical model. Models are expressed in huge polynomials and do not provide us with any useful information, but we are interested in values of influence coefficients of variables included in these models, because they have the greatest impact on the value of GDP and national economic security.

According to our calculations, the key features of conditions determining the value of GDP and respectively have the greatest influence coefficients on development of the national information economy are: the value of internal gross R\&D expenses; the value of state debt; the value of export of hi-tech goods (Table 2). The achieved results describe the real state of national information economy and are adequate to up-to-date processes. Our results prove the key qualitative features of optimal model for social and economic development. Therefore, the experience of countries with developed information economy show that their success and high level of competitiveness rely on adequate determination of prospective development directions and effective implementation of innovations in production.

Table 2. Clustering of Synthesized Models by Influence Coefficients

Tabela 2. Grupowanie zsyntetyzowanych modeli według współczynników wpływu

\begin{tabular}{|c|c|c|c|c|c|c|l|}
\hline \multicolumn{7}{|c|}{ The Influence Coefficients of } & \multirow{2}{*}{ Variables in models, millions of US dollars } \\
Variables in Models for 7 Clusters, \% & \\
\hline $\mathbf{1}$ & $\mathbf{2}$ & $\mathbf{3}$ & $\mathbf{4}$ & $\mathbf{5}$ & $\mathbf{6}$ & $\mathbf{7}$ & \\
\hline 0 & 0 & 0 & 1 & 0 & 0 & 0 & GDP per capita \\
\hline 9 & 16 & 0 & 4 & 0 & 2 & 0 & Foreign trade turnover per capita \\
\hline $\mathbf{2 7}$ & $\mathbf{7 1}$ & $\mathbf{0}$ & $\mathbf{4 7}$ & $\mathbf{8 9}$ & $\mathbf{7 4}$ & $\mathbf{0}$ & State debt \\
\hline 6 & 0 & 2 & 1 & 3 & 5 & 0 & Foreign debt \\
\hline $\mathbf{0}$ & $\mathbf{0}$ & $\mathbf{1 9}$ & $\mathbf{3}$ & $\mathbf{0}$ & $\mathbf{0}$ & $\mathbf{7 8}$ & High-tech commodity export \\
\hline 0 & 0 & 3 & 9 & 0 & 2 & 0 & ICT commodity export \\
\hline 2 & 0 & 3 & 0 & 0 & 0 & 0 & ICT commodity import \\
\hline $\mathbf{5 6}$ & $\mathbf{1 2}$ & $\mathbf{6 7}$ & $\mathbf{5 3}$ & $\mathbf{0}$ & $\mathbf{0}$ & $\mathbf{0}$ & Gross domestic expenditure on $\mathbf{R} \boldsymbol{\text { GD }}$ \\
\hline
\end{tabular}

Source: own processing. 


\section{Conclusion}

Thus, analyzing models of countries with developed information economies, we determined the qualitative and quantitative determinants of optimal model for social and economic development of countries with developed information societies.

Qualitative features consist of economic and social blocks. The key element of economic block is the goal-oriented and considered strategy for the national sustainable social and economic development. The main component of social block is the development of civil society. Therefore, the experience of countries with developed information economy show that their success and high level of competitiveness rely on adequate determination of prospective development directions and effective implementation of innovations in production.

Countries-leaders by IT-industry, namely, countries with developed information economy, as a rule, show higher indicators of competitiveness and living standards. Countries-leaders by IT-industry development, namely, with developed information economy, have higher levels of competitiveness and living standards. The high employment rates guarantee the dynamic economy and civil society. Implementing strategies for social and economic development of countries with developed information economy maximally ensure the protection of national economic interests. Therefore, the models for sustainable social and economic development objectively form the basis of economic security of countries with information economy.

\section{Bibliography}

Ahmadi M.H., Ahmadi M.A., Mehrpooya M., Rosen M.A., Using GMDH Neural Networks to Model the Power and Torque of a Stirling Engine, Sustainability, 2015, 7 (2), 2243-2255.

Dumor K., Yao L., Estimating China's Trade with Its Partner Countries within the Belt and Road Initiative Using Neural Network Analysis, Sustainability, 2019, 11 (5), 1449.

Dubikovsky S., The End of Epoch: the Fatal Choice of Humanity, Fiery Lel, Kyiv 2019.

The Global Information Technology Report, Available online: http://www3.weforum.org/docs/ GITR2016/WEF_GITR_Full_Report.pdf (accessed on 25 January 2019).

Habermas J., The Structural Transformation of the Public Sphere, The MIT Press, Cambridge Massachusetts 1991.

Ivajhnenko A.G., The Inductive Method of Complex System Self-organization, Naukova Dumka, Kyiv 1981.

Ivakhnenko G.A., Inductive Methods of Analysis and Forecasting of Complex Economic Systems, Cybercenter of the National Academy of Sciences of Ukraine, Natonal Institute for Strategic Research, Kyiv. Available online: http://www.GMDH.net (accessed on 25 January 2019). 
Schwab K., The Fourth Industrial Revolution, Crown Business, New York 2017.

Shumpeter J., Theory of Economic Development. Capitalism, Socialism and Democracy, EKSMO, Moscow 2007.

Yang L., Yang H., Liu H., GMDH-Based Semi-Supervised Feature Selection for Electricity Load Classification Forecasting, Sustainability, 2018, 10 (1), 217.

\section{Authors' resume:}

Yevhenii Alimpiiev is habilitated doctor of economic sciences. Specializes in the field of macroeconomics and public finances. His interests concern the study of macroeconomic equilibrium and economic security, the role of the state in stimulating economic development. He is the author of publications on the use of econometric models in assessing macroeconomic dynamics.

Stanislav Dubikovsky received his Ph.D. in the Economic Security of the State from University of Economics and Law "KROK" in Kyiv. Since 2015 he is a Director of Institute of Social and Economic Development in Kyiv. His research interests include sustainable development and information society challenges, state and global security. He is the author of the monograph "The Edge of Epoch: The Fatal Choice of Humanity" and more than 20 publications in scientific journal and proceedings of international conferences.

Volodymyr Tokar is Professor of International Finance at the Faculty of International Economics and Management of Kyiv National Economic University named after Vadym Hetman in Kyiv (Ukraine). His research focuses on innovative economy, economic security and gender studies. He has published as the (co)author more than 100 monographs, articles and proceedings of international conferences.

\section{Nota o Autorach:}

Yevhenii Alimpiiev - doktor habilitowany nauk ekonomicznych. Specjalizuje się w dziedzinie makroekonomii $i$ finansów publicznych. Jego zainteresowania dotycza badań równowagi makroekonomicznej i bezpieczeństwa ekonomicznego, roli państwa w stymulowaniu rozwoju gospodarczego. Jest autorem publikacji dotyczacych wykorzystania modeli ekonometrycznych w ocenie dynamiki makroekonomicznej.

Stanislav Dubikovsky otrzymał doktorat $w$ dziedzinie bezpieczeństwo gospodarcze państwa na Uniwersytecie Ekonomii i Prawa „KROK” w Kijowie. Od 2015 r. jest dyrektorem Instytutu Rozwoju Społeczno-Gospodarczego w Kijowie. Jego zainteresowania badawcze obejmuja zrównoważony rozwój $i$ wyzwania społeczeństwa informacyjnego, bezpieczeństwo państwa i bezpieczeństwo globalne. Jest autorem monografii „Krawędź epoki: fatalny wybór ludzkości” oraz ponad 20 publikacji $w$ czasopiśmie naukowym i prac międzynarodowych konferencji.

Volodymyr Tokar jest profesorem finansów międzynarodowych na Wydziale Międzynarodowej Ekonomii i Zarzadzania Kijowskiego Narodowego Uniwersytetu Ekonomicznego im. Vadyma Hetmana w Kijowie (Ukraina). Jego badania skupiaja się na innowacyjnej gospodarce, bezpieczeństwie ekonomicznym i badaniach nad płcią. Opublikował jako (współ)autor ponad 100 monografii, artykułów i materiałów z międzynarodowych konferencji. 


\section{Contact/Kontakt:}

Yevhenii Alimpiiev

e-mail: yevhenii.alimpiiev@gmail.com

Stanislav Dubikovsky

e-mail: stas.d76@gmail.com

Volodymyr Tokar

e-mail:tokarww@ukr.net

The contribution of particular co-authors to preparation of the paper:

Wkład poszczególnych autorów w przygotowanie publikacji:

Yevhenii Alimpiiev - 25\%, Stanislav Dubikovsky - 50\%, Volodymyr Tokar - 25\%. 